\title{
CO-OPERATIVE \\ LEADERS NEED TO \\ LEAD THE WAY ON \\ GLOBAL AND LOCAL \\ SDG ADOPTION
}

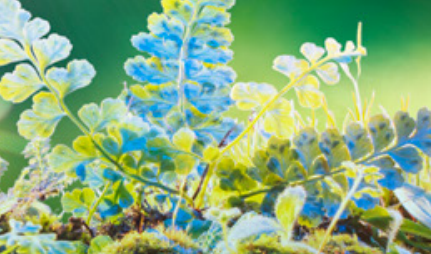

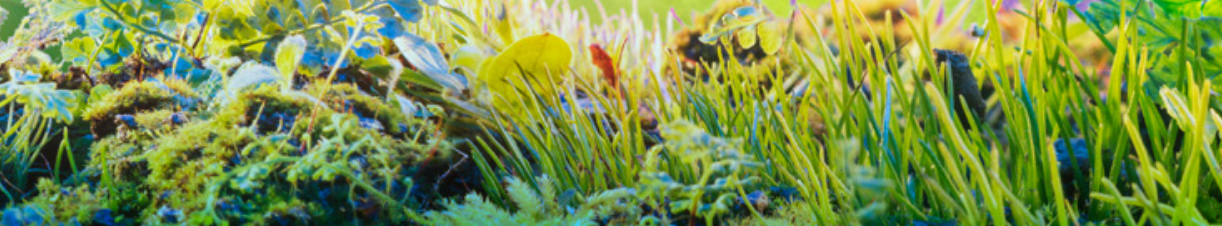

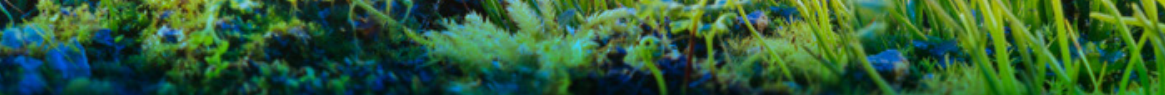

DAPHNE RIXON, SAINT MARY'S UNIVERSITY,

CANADA AND FIONA DUGUID,

SAINT MARY'S UNIVERSITY, CANADA 


\section{Executive Summary}

Co-operative industry associations must implement policies that encourage co-operatives to embrace the SDGs in a way that reflects the co-operative difference. Reporting on the SDGs in the context of the seven principles enables co-operatives to illustrate their difference from investor-owned businesses (IOB) who are increasingly reporting on SDG performance. The brief includes key recommendations that are critical in facilitating cooperatives' adoption of the SDGs and in reporting their performance relative to the SDGs and the seven principles.

Last updated February 2022 


\section{Introduction}

The SDGs are not merely an opportunity to trumpet how a government, business, organization or co-operative is contributing to sustainable development - a soundbite, a promo moment. When reflected on, embraced and implemented in a critical and meaningful manner the opportunity for a better understanding of impact and drive for positive change can be very real. There is a tremendous need to improve co-operatives' awareness of the SDGs and to encourage the co-operative sector to implement and report based on the SDGs. To help co-operatives better understand their impact in terms of the SDGs, various co-operative industry associations should promote not only adopting SDG initiatives, but also champion a framework to design, measure and report on the co-operative sector's SDG impact. Accountability is enhanced when co-operatives compare their SDG performance to their peers.

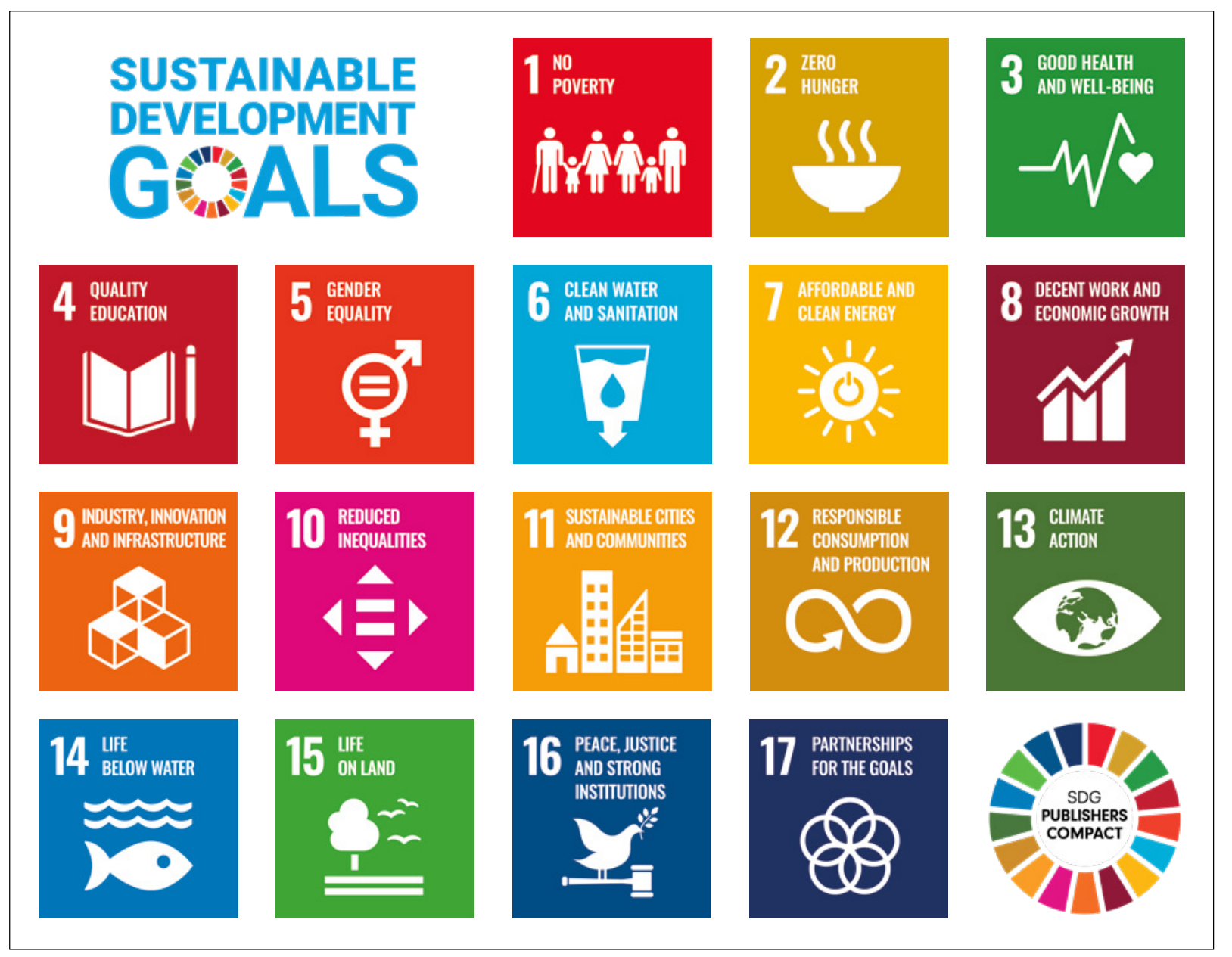

The International Co-operative Alliance's (ICA) Statement on the Co-operative Identity includes a commonly held definition for co-operatives being "an autonomous association of persons united voluntarily to meet their common economic, social and cultural needs and aspirations through a jointly owned and democratically-controlled enterprise" (ICA, n/a). In order to put this definition into practice, co-operatives also embrace seven principles including:

voluntary and open membership; democratic member control; autonomy and independence; education, training and information; co-operation among co-operatives; and concern for community. These principles are enshrined through incorporation and via the co-operatives' bylaws.

To support this call, together with 16 co-operative participants, we have developed a SDG indicators framework that can be used by co-operative associations and co-operatives to promote SDG adoption to their members.

\section{Findings}

Co-operatives have an opportunity to demonstrate their unique difference from other types of business enterprises through their non-financial performance reporting. Firstly, co-operatives can report on the extent to which they have operationalized the seven principles of co-operatives and secondly, they can report on their performance relative to the United Nations SDGs. Thirdly, we argue that, in order to better distinguish themselves from investor-owned businesses (IOBs), when measuring their SDG performance, co-operatives can consider linking the SDGs to the seven principles, whenever feasible. Indeed, we contend that reporting on SDGs in isolation of the seven principles does not contribute to demonstrating the co-operative difference.

Starting with a list of 470 potential SDG metrics, the research team narrowed down the list to 50 metrics which were then evaluated by the project participants using four criteria: importance for stakeholders, feasibility, relativity to other metrics or indicators, and sector specificity. The participating co-operatives identified the following 20 metrics which met the four criteria. 


\begin{tabular}{|c|c|c|c|c|}
\hline & Metric & Indicator & SDG & $\begin{array}{l}\text { Co-op } \\
\text { Principle }\end{array}$ \\
\hline 1 & $\begin{array}{l}\text { How many members withdrew their } \\
\text { membership in your most recently } \\
\text { completed fiscal year? }\end{array}$ & Participation & 8,16 & $1,2,3$ \\
\hline 2 & How many members attended the AGM? & $\begin{array}{l}\text { Participation, } \\
\text { Transparency }\end{array}$ & 10,16 & 2 \\
\hline 3 & Does your co-op share information? & Transparency & $\begin{array}{l}8,9,10,11,12 \\
13,16\end{array}$ & 5,7 \\
\hline 4 & $\begin{array}{l}\text { Does your co-op/mutual receive donated } \\
\text { services or capital goods that helps its } \\
\text { existence? }\end{array}$ & $\begin{array}{l}\text { Independence, } \\
\text { Collaboration }\end{array}$ & 16,17 & 4,6 \\
\hline 5 & $\begin{array}{l}\text { Has your co-op issued shares to non- } \\
\text { members? }\end{array}$ & $\begin{array}{l}\text { Independence, } \\
\text { Economic equality and equity }\end{array}$ & 1,16 & 3,4 \\
\hline 6 & $\begin{array}{l}\text { How was the surplus distributed at the end } \\
\text { of the last fiscal year? }\end{array}$ & Economic equality and equity & $1,10,11,16$ & 3 \\
\hline 7 & $\begin{array}{l}\text { How many employees (FTE) in each of } \\
\text { these categories? }\end{array}$ & Equality and equity & 8,10 & N/A \\
\hline 8 & $\begin{array}{l}\text { How many people are in each of the } \\
\text { following diversity categories? }\end{array}$ & Equality and equity & $5,8,10,16$ & 1,2 \\
\hline 9 & $\begin{array}{l}\text { What is the annual remuneration of the } \\
\text { highest paid (FTE) employee and the lowest } \\
\text { paid (FTE) employee, including bonuses } \\
\text { and other benefits? }\end{array}$ & Equality and equity & 8,10 & N/A \\
\hline 10 & $\begin{array}{l}\text { Does your co-op provide benefits to your } \\
\text { employees? }\end{array}$ & Decent workplaces & $3,8,10,11,16$ & N/A \\
\hline 11 & Does your co-operative produce goods? & Responsible production & 12 & 7 \\
\hline 12 & $\begin{array}{l}\text { How many co-ops does your co-op work } \\
\text { with? }\end{array}$ & Collaboration & $9,11,17$ & 6 \\
\hline 13 & $\begin{array}{l}\text { How much money is spent on education } \\
\text { and training in your co-op? }\end{array}$ & Lifelong learning & 4,8 & 5 \\
\hline 14 & $\begin{array}{l}\text { How many employees and managers are } \\
\text { recruited locally for the co-op's major } \\
\text { operating sites? }\end{array}$ & $\begin{array}{l}\text { Local economic development } \\
\text { and stability }\end{array}$ & $8,11,16$ & 7 \\
\hline 15 & $\begin{array}{l}\text { Does your co-op have a sustainable } \\
\text { procurement policy? }\end{array}$ & $\begin{array}{l}\text { Local economic development } \\
\text { and stability, } \\
\text { Responsible production, } \\
\text { Environmental sustainability }\end{array}$ & 11,12 & 7 \\
\hline 16 & $\begin{array}{l}\text { Does your co-op have a Greenhouse Gas } \\
\text { inventory? }\end{array}$ & Environmental sustainability & $7,9,11,13$ & 7 \\
\hline 17 & $\begin{array}{l}\text { Does your co-op work to reduce its energy } \\
\text { consumption? }\end{array}$ & Environmental sustainability & $7,9,11,13$ & 7 \\
\hline 18 & $\begin{array}{l}\text { Does your co-op work to reduce its water } \\
\text { consumption? }\end{array}$ & Environmental sustainability & 6,14 & 7 \\
\hline 19 & Does your co-op work to divert its waste? & Environmental sustainability & $11,12,15$ & 7 \\
\hline 20 & $\begin{array}{l}\text { How much does your co-op donate to } \\
\text { other activities that support SDGs? }\end{array}$ & Sustainability & 11 & 7 \\
\hline
\end{tabular}


As depicted in Table 2, the most commonly aligned SDG is SDG 11, followed by SDG 16, and SDG 8. This is not surprising given the values that are associated with co-operatives. Also given the universal application intention of this framework and selection criteria for the participants to select metrics, it is not surprising that more specific SDGs like SDG 2, 3, 4, 5, 6, 14, and 15 are not more present.

\begin{tabular}{|l|c|c|c|c|c|c|c|c|c|c|c|c|c|c|c|c|c|}
\hline SDG\# & 1 & 2 & 3 & 4 & 5 & 6 & 7 & 8 & 9 & 10 & 11 & 12 & 13 & 14 & 15 & 16 & 17 \\
\hline Total & 2 & 0 & 1 & 1 & 1 & 1 & 2 & 8 & 4 & 7 & 10 & 4 & 3 & 1 & 1 & 9 & 2 \\
\hline
\end{tabular}

Table 2: SDGs represented in the 20 metrics

Table 3 illustrates the alignment of the co-operative principles to the 20 metrics. All principles can be reported on by the selected metrics and with good coverage.

\begin{tabular}{|l|l|l|l|l|l|l|l|}
\hline Co-operative Principles & 1 & 2 & 3 & 4 & 5 & 6 & 7 \\
\hline Total & 2 & 3 & 3 & 2 & 2 & 2 & 9 \\
\hline
\end{tabular}

Table 3: Co-operative Principles represented in the 20 metrics

The correlation between the SDGs and co-operative principles highlighted the deficiency in the principles around decent work and workplaces. All but three metrics selected by participants can be linked to one or more of the seven principles. SDG 8, is not reflected in the seven principles even when stretching our understanding of the principles. This is concerning since most co-operatives are associated, correctly or incorrectly, with providing reasonable wages and good working conditions.

Overall, there was a tendency to use Principle 7. Concern for Community, as a catch-all category for SDGs. Because the co-operative principles do not explicitly discuss the environment, P7 became the landing place for environmental sustainability metrics.

\section{Implications}

What does the development and implementation of co-operative specific SDG framework for measuring and reporting co-operatives' impact offer? While most of the participants had a high-medium level awareness of the SDGs, there is an opportunity for a streamline measurement and reporting framework to be taken up by the co-operative sector. This is especially the case for small to medium-sized co-operatives that do not have the resources to develop a framework to report on their SDG performance. This framework is the foundation for a data gathering system for co-operatives to collect and report on their SDG performance data, thus creating benchmarks within the co-operative sector.

\section{Recommendations}

- Development of an online webtool to facilitate data collection for co-operatives to allow them to better understand and communicate their SDG impact, compare against their peers, and foster performance benchmarking.

- Co-operative sector associations should implement policies that support awareness raising and adoption of the SDGs by the co-operative sector.

- The ICA should consider reflecting environmental sustainability in a more meaningful way. The 'catchall' Principle 7 does not do justice to the dire need to assess impact on the planet.

\section{Contact details}

Professor Daphne Rixon, Saint Mary's University

daphne.rixon@smu.ca

Dr Fiona Duguid, Saint Mary's University

fduguidagmail.com

- The ICA should address the lack of a principle reflecting decent work. Such a principle would allow for cooperatives to embrace the creation and celebration of workplaces that are fair, safe and just for employees.

- Co-operative sector associations should formally adopt a co-operative performance framework that includes the SDGs and the seven principles. 


\section{References}

Beishenaly, N. \& Eum, H. (November 10, 2021). How Co-operatives Drive the Change: A SDG Framework for Cooperatives, International Co-operative Alliance. Presentation. ICA and the Centre for Cooperative Entrepreneurship of the University of Leuven.

Duguid, F. and D. Balkin (2016). Talking the Talk: Canadian Co-operatives and Sustainability Reporting, Journal of Co-operative Accounting and Reporting, 4 (1).

Goyannes Gusmão Caiado. (2018). A literature-based review on potentials and constraints in the implementation of the sustainable development goals. Journal of Cleaner Production, 198(October), 1276-1288. https://doi. org/10.1016/j.jclepro.2018.07.102

ICA. (n/d). Retrieved from https://www.ica.coop/en/co-operatives/co-operative-identity

Novkovic, S. (2020). Sustainability Indicators from the Cooperative Perspective. Prepared for the UNRISD project Sustainable Development Performance Indicators. SMU, Halifax.

Rixon, D. and F. Duguid (2018). A Framework for Developing Co-operative Benchmarks, Journal of Co-operative Studies, Vol. 5. No. 1, 5 - 16.

Rowlston, N. and F. Duguid (2020). Co-operative Sustainability Performance Measurement: The Role of the Co-op Principles and UN Sustainable Development Goals in the Reporting Model, International Journal of Co-operative Accounting and Management, 3 (2), 4 - 19.

Sustainable Development Solutions Network. (2015). Indicators and Monitoring Framework for the Sustainable Development Goals: Launching a Data Revolution for the SDGs. Geneva: United Nations.

Stafford-Smith, M., D. Griggs, O. Gaffney, F. Ullah, B. Reyers, N. Kanie, B. Stigson, P. Shrivastava, M. Leach \& D. O'Connell (2017). Integration: the key to implementing the Sustainable Development Goals, Sustainability Science, 12, 911-919.

Wanyama, F. O. (2014). Cooperatives and the Sustainable Development Goals: A Contribution to the Post-2015 Development Debate. A policy brief [Publication]. http://www.ilo.org/empent/Publications/WCMS_240640/lang--en/index.htm 